\title{
Gender differences in low-income non-users' attitude towards Wireless Internet Gateway cellphone banking
}

\author{
J. Nel* and T. Raleting \\ University of the Free State, \\ PO Box 339, Bloemfontein 9300, Republic of South Africa \\ Nelj@ufs.ac.za
}

Received September 2011

\begin{abstract}
Globally the adoption of cellphone banking is proceeding more slowly than anticipated. To address this managerial dilemma, the aim of this paper is to investigate the moderating effect of gender on low-income non-users' attitude formation towards Wireless Internet Gateway (WIG) cellphone banking. An understanding of whether and to what extent gender moderates the formation of attitude can assist marketing managers in developing more effective marketing strategies to enhance adoption. The originality of the research is that it investigates gender differences in WIG-cellphone banking adoption behaviour of low-income non-users of this type of cellphone banking application. Literature on technology adoption, self-efficacy, facilitating conditions, risk and cost is reviewed to provide theoretical support for inclusion of the constructs in the conceptual model and to develop gender difference hypotheses. To assess the moderating effect of gender, a multi-group analysis with SmartPLS is conducted. The results of the multi-group analysis indicate that for males the influences of Usefulness on Attitude, Facilitating conditions on Self-efficacy and Ease of use, and Cost on Usefulness are stronger than for females and significantly different. On the other hand, the influences of Ease of use on Attitude, Self-efficacy on Ease of use and Facilitating conditions on Perceived usefulness are stronger for females than males and significantly different. These results may also be useful to marketing managers of other text-based mobile self-services. Furthermore, more confirmation for the determinants of Usefulness and Ease of use in a private usage and mobile service context is presented.
\end{abstract}

*To whom all correspondence should be addressed.

\section{Introduction}

Despite the advantages of cellphone banking such as time saving, convenience and ease of use, the adoption rate of cellphone banking is not as expected. Shen (2010) reports that in the US close to 10 million bank customers were using mobile banking in 2009. In South Africa, although the number of cellphone banking users is on the increase, only $28 \%$ of bank customers (taking into account that approximately $64 \%$ of bank customers did not use Internet or cellphone banking) are using cellphone banking (Kabanda, Brown, Nyamakura \& Keshav, 2010). Thus, the managerial dilemma that underpins this study is the slow adoption of cellphone banking. From the perspective of banks that developed the cellphone banking systems in South Africa, a vastly improved number of customers ought to use cellphone banking in order to justify their investments and operational expenditure. Therefore, gaining an understanding of non-users' cellphone adoption behaviour can enable banks to develop effective strategies to enhance the adoption rate of this innovation.

Previous studies with regard to non-users of cellphone banking focused primarily on comparing the adoption behaviour of non-users with those of users (e.g. Laforet \& Li, 2005; Suoranta \& Mattila, 2004). Although such research contributes to the understanding of non-user adoption behaviour, a deeper understanding can be achieved by considering the effects of moderating variables in adoption behaviour. Gender has been identified as a key variable in moderating beliefs regarding the use of information technology-related innovations (Hwang, 2010), but sufficient research on the moderating effect of gender in cellphone banking adoption behaviour has not been undertaken up to now (Riquelme \& Rios, 2010). Furthermore, Gu, Lee and Suh (2009) point out that cellphone banking adoption behaviour can be studied better if the research focuses on a specific type of cellphone banking, such as virtual machine or WIG (Wireless Internet Gateway). This is the second limitation in this stream of research (cellphone banking and non-users' adoption behaviour): the lack of research on adoption behaviour with regard to a specific type of cellphone banking application. A third limitation of the existing research on cellphone banking is that previous research did not investigate the adoption behaviour of low-income earners. Income can be an important factor in cellphone banking adoption since lower-income consumers often resist services with continuing costs (Porter \& Donthu, 2006). The research question is therefore as follows: Do male and female lowincome non-users of cellphone banking significantly differ in their formation of attitude (formation of attitude refers to the determinants that influence attitude) towards WIGcellphone banking? Attitude towards a technology is an 
important variable as it is an antecedent of Intention in the Technology Acceptance Model of Davis (1989). Furthermore, attitude serves as a determinant of actual behaviour in many other studies and an extensive body of literature demonstrates the importance of attitude on behaviours (Alsajjan \& Dennis, 2009). WIG-cellphone banking is also an appropriate cellphone banking application in the context of the study as it costs less than Wireless Application Protocol (WAP) cellphone banking (Brown, Cajee, Davies \& Stroebel, 2003), and may therefore appeal more to low-income earners. The primary objective is therefore to determine if gender moderates the formation of Attitude towards WIG-cellphone banking of low-income non-users of the mobile service. If the research can find evidence that male and female non-users differ in their formation of attitude towards WIG-cellphone banking, marketing managers can adapt their marketing strategies with a view to enhancing the adoption rate.

In the next section the theory underpinning the proposed conceptual model of attitude formation towards WIGcellphone banking will be presented, as well as the theory considered in the development of the gender difference hypotheses. This will be followed by an explanation of the research design and method, assessment of construct reliability and validity, and the multi-group analysis. Next, the results of the multi-group analysis will be discussed and managerial implications will be elucidated from the findings of the study. The study will conclude with limitations and areas for future research.

\section{Theoretical development}

Figure 1 shows the research model. The model shows that gender will moderate the nine relationships in the conceptual model of attitude formation towards WIGcellphone banking.

\section{Perceived usefulness and Perceived ease of use}

According to the Technology Acceptance Model (TAM), Perceived usefulness and Perceived ease of use are the two salient internal beliefs explaining Attitude towards a technology (Davis, 1989). According to Davis (1989), the Usefulness construct in information systems (IS) implies that a system can be used advantageously and that the user believes in the existence of a positive user-performance relationship. On the other hand, Ease of use refers to 'freedom from difficultly or great effort'. Therefore, systems perceived to be easier to use are more likely to be accepted by users (Davis, 1989). The Ease of use of a system also enhances the Usefulness of the system. Thus, Perceived ease of use positively influences Perceived usefulness (Davis, 1989). Based on the definitions of these two internal beliefs in Davis (1989), Perceived usefulness and Perceived ease of use are defined in this study as 'the degree to which a person believes that using WIG-cellphone banking will enhance his/her performance of banking activities' and 'the extent to which a person believes that using WIG-cellphone banking will be free of effort'. Previous research on the moderating effect of gender has shown that men consider usefulness to a greater extent, while women are more strongly influenced by ease of use in making their decisions about technology adoption (Ong \& Lai, 2006; Sun \& Zhang, 2006; Venkatesh, 2000). However, previous research on the moderating effect of gender on the Perceived ease of use - Perceived usefulness relationship shows mixed results. Empirical results in Nysveen, Pedersen and Thorbjørnsen (2005) and Im, Kim and Han (2008) show that the influence of Perceived ease of use on Perceived usefulness is stronger for males than for females, whilst Ong and Lai (2006) find the opposite influence. Moreover, in Lai and Li (2005) and Venkatesh and Morris (2000) gender does not moderate the Perceived ease of use - Perceived usefulness relationship. Conversely, in Ong and Lai (2006) and Riquelme and Rios (2010) the results of the study show that gender does moderate the Perceived ease of use - Perceived usefulness relationship. In the light of these conflicting results, only a significant difference between males and females for the Perceived ease of use - Perceived usefulness relationship is hypothesized. In accordance with the TAM theory and the discussion on gender differences, the following hypotheses are included in the study:

H1. Perceived usefulness positively influences Attitude towards WIG-cellphone banking more strongly for males than for females.

H2. Perceived ease of use positively influences Attitude towards WIG-cellphone banking more strongly for females than for males.

H3. The influence of Perceived ease of use on the Perceived Usefulness of WIG-cellphone will significantly differ between males and females.

\section{Perceived self-efficacy and Facilitating conditions}

Previous research on technology adoption behaviour in the cellphone banking context (Luarn \& Lin, 2005) and SMS usage (Nysveen et al., 2005) has found that Perceived behavioural control can be an important predictor in adoption behaviour. According to Taylor and Todd (1995), Perceived behavioural control consists of Perceived selfefficacy and Facilitating conditions. Compeau and Higgins (1995) define Self-efficacy as an individual's perceptions of his or her ability to use technology in the accomplishment of a task. More importantly, individuals who consider a technology too complex to use and believe that they will never be able to control the technology will prefer to avoid it and are less likely to use it (Igbaria \& Iivari, 1995). In the study of Wang, Lin and Luarn (2006) the results show that Self-efficacy influences Ease of use in the mobile service context. This is because Self-efficacy relates to skill, which corresponds with Ease of use (Mathieson, 1991). According to Dabholkar and Bagozzi (2002) and Ong and Lai (2006), consumers with greater self-efficacy can be expected to have more confidence in their ability to use technologybased self-service, and therefore Ease of use will not be as important to them as to consumers with less confidence in their own abilities. Following gender stereotyping, women display higher levels of anxiety and lower levels of Selfefficacy towards the use of new technology than men (Ong \& Lai, 2006; Roca, Chiu \& Martínez, 2006). Furthermore women are more motivated by process factors than men and therefore it can be expected that the low evaluation of 
computer self-efficacy by females will cause an increase in the salience of perceptions of ease of use. (Ong \& Lai, 2006). Hence, the influence of Perceived self-efficacy on Perceived ease of use should be stronger for females than for males. Facilitating conditions are the 'external environments of helping users overcome barriers and hurdles to use of IT' (Gu et al., 2009). According to $\mathrm{Gu}$ et al. (2009), users will perceive cellphone banking as easy to use when they recognize that there are environmental conditions to help them in learning how to use mobile banking, even though they cannot use it skilfully. Facilitating conditions could also influence Self-efficacy perceptions, because the availability of certain resources such as support can enhance non-users' belief that they will be able to use cellphone banking to accomplish specific banking transactions. According to Venkatesh et al. (2008), facilitating conditions should have a more salient influence on females, as women are more process orientated. The availability of facilitating conditions such as external help, support, training, etc., will help women to learn more about the process. Thus, for women, facilitating conditions should more strongly influence perceptions of Ease of use and Selfefficacy. Considering the above arguments the following hypotheses are included in the study:

H4. Perceived self-efficacy positively influences Perceived ease of use of WIG-cellphone banking more strongly for females than for males.

H5. Facilitating conditions positively influences Perceived ease of use of WIG-cellphone banking more strongly for females than for males.

H6. Facilitating conditions positively influences Perceived self-efficacy of WIG-cellphone banking more strongly for females than for males.

H7. Facilitating conditions positively influences Perceived usefulness of WIG-cellphone banking more strongly for females than for males.

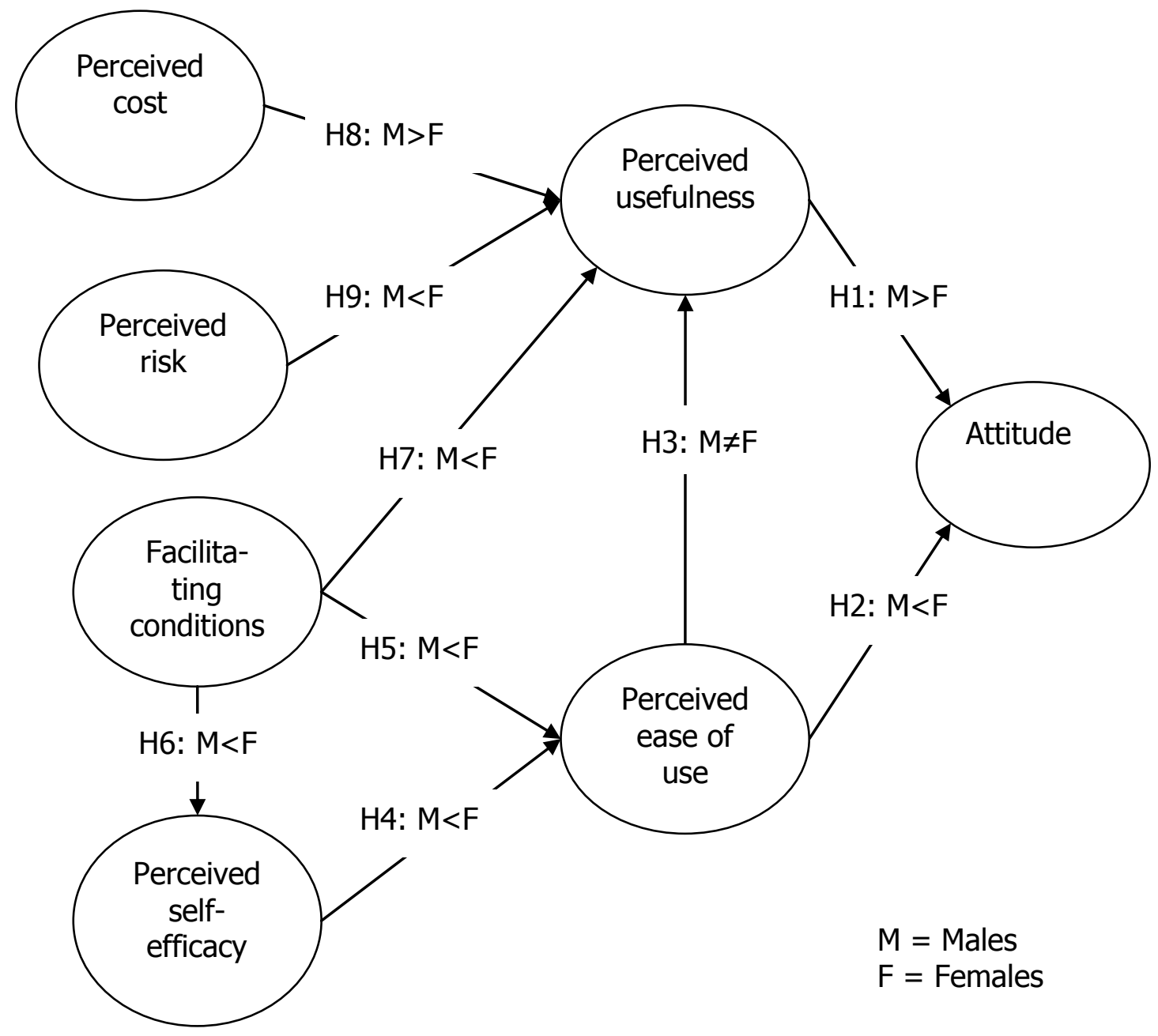

Fig. 1. Theoretical model of attitude formation towards WIG-cellphone banking 


\section{Perceived cost}

In reports on cellphone banking it was mentioned that the cost of cellphone banking can have a negative influence on adoption behaviour. For example, Naidu (2006) reports that research done by World Wide Worx shows that 44 percent of the respondents indicated that a decrease in the cost of transactions would convince them to use cellphone banking. It is also reported that, although clients of two major South African banks showed that there was a strong demand for cellphone banking facilities during free cellphone transactions for limited periods, both financial institutions noticed a drop in usage when fees were introduced (Whitfield, 2006). As already mentioned low-income consumers often resist services with continuing costs. Therefore, it is reasonable to assert that for low-income nonusers cost can be a deterrent to use WIG-cellphone banking. In the study of Wang et al. (2006) empirical evidence is presented that the availability of financial resources has a positive significant influence on Perceived usefulness. Given that the target population is low-income earners, it is reasonable to argue that they have less financial resources available to use WIG-cellphone banking and therefore the cost of WIG-cellphone banking should be a major factor influencing the Perceived usefulness of WIG-cellphone banking. Therefore, we postulate that the Perceived cost of WIG-cellphone banking should have a negative influence on Perceived usefulness because of the limited financial resources available to low-income earners. The influence of Perceived cost on Perceived usefulness should be more salient for males who are motivated by productivity goals, as it can impede the use of WIG-cellphone banking. Considering these arguments, the following hypothesis is formulated for the study.

H8. Perceived cost negatively influences Perceived usefulness of WIG-cellphone banking more strongly for males than for females.

\section{Perceived risk}

The Perceived risk of using an e-service can be a prominent barrier to consumer acceptance (Featherman \& Pavlou, 2003), as it can be an important determinant of consumers' attitude towards online transaction (Wu \& Chen, 2005; Wu $\&$ Wang, 2005). In the internet banking context (Tan \& Teo, 2000) and the cellphone banking context (Riquelme \& Rios, 2010), Perceived risk has been identified as a predictor of adoption behavior. Based on the definitions of Perceived risk in Lee (2009) and Featherman and Pavlou (2003), Perceived risk is for the purpose of this study defined as 'the subjective determined expectation of financial loss by a bank customer in contemplating the use of WIG-cellphone banking'. Prior research on Risk and online buying has proposed that Risk is a key factor in influencing females' perception of Web shopping (see, e.g. Van Slyke, Comunale and Belanger, (2002)) and empirical evidence was found that females perceive more risk than males in online buying (Garbarino \& Strahilevitz, 2004). This gender difference may be due to the fact that men are generally more willing to take risks (Kim, Lehto \& Morrison (2007); Powell \& Ansic (1997) and that females show more anxiety in the use of technology (see, e.g. Li and Kirkup (2007); Ong and Lai,
(2006)). In the study of Amin, Hamid, Tanakinjal and Lada (2006) it is also found that females are more concerned about the security of cellphone banking than males. This suggests that females could perceive more risk in the use of the cellphone banking than men. Based on the discussion above, the following hypothesis is included:

H9. Perceived risk negatively influences Perceived usefulness of WIG-cellphone banking more strongly for females than for males.

\section{Research design and method}

\section{Sampling}

The target population of the study was low-income earners owning cellphones without access to the Internet at home or at work in a major South African city. In the study, lowincome earners are defined as individuals earning R11 000 a month and less. This is based on reviewing criteria used by the four major South African banks in defining low-income earners with regard to home loan applications. Internet access is an important factor to consider as cellphone banking should be the more rational option for individuals without regular/easy access to the Internet. The data were collected by means of a self-administered questionnaire distributed at the place of employment. From the study population a non-probability sample of 465 respondents was drawn.

\section{Data collection}

A 40-item questionnaire was designed with 9 items relating to demographic and general questions and 31 items to useracceptance behaviour. Since the respondents were non-users the term 'WIG-cellphone banking' was replaced with the non-technical term for this type of cellphone banking application 'SMS-cellphone banking' and a brief explanation of SMS-cellphone banking was presented at the beginning of the questionnaire. Questions relating to beliefs were measured using a five-point Likert-type scale (1=absolutely disagree, $2=$ disagree, $3=$ neither agree nor disagree, 4=agree, $5=$ absolutely agree). The scale used to measure Attitude was based on the scales used by Kuo and Yen (2009) and Grabnet-Krăuter and Kaluscha (2003). The items used by Davis (1989) to measure Ease of use were adapted for the study, as well as the items by Wang and Wang (2008) to measure Self-efficacy towards a specific mobile service. More context-specific scales are used for Perceived usefulness, based on the scale used by Davis (1989) and online cellphone banking marketing materials of banks in South Africa; Perceived risk, considering scales used in Wu and Wang (2005) and Featherman and Pavlou (2003); Perceived Cost, considering the scale used in Luarn and Lin (2005) and real-world costs of WIG-cellphone banking; and Facilitating conditions, considering scales used in Akinci, Aksoy and Atilgan (2004), Cheung, Chang and Lai (2000) and Pedersen (2005). The items used to measure each construct are listed in Annexure A. 


\section{Analysis plan}

Before the analysis started the data was tested for multivariate normality. It was found that the data exhibits non-normality. AMOS 18.0 co-variance based structural equation modeling programme only includes maximum likelihood estimation and not also robust-maximum likelihood estimation which is more appropriate to use for data deviating from multi-variate normality. Hence, ignoring the absence of multi-variate normality and continuing the analysis with AMOS 18.0 would be considered a methodological error. Therefore, to test the hypotheses, a structural equation modelling process using a partial least squares (PLS) analysis with SMART-PLS 2.0 (Ringle, Wende \& Will, 2005) was adopted. The variance-based PLS procedure was used because PLS is robust to deviations from normality (Henseler, Ringle \& Sinkovics, 2009). The path coefficients were compared, based on Wynne Chin, as described by Keil, Tan, Wei and Saarin (2000). To generate $\mathrm{t}$-values to assess convergent validity and test the hypotheses, bootstrapping with 500 sub-samples (Chinn, 1998) was used.

In structural equation modeling, a primary concern when comparing structural weights across groups is ensuring that the construct measures are invariant across the groups. In other words, measurement invariance must be confirmed. If measurement invariance cannot be established, the differences in path coefficients cannot be fully attributed to true relationships, because respondents from different groups might have systematically interpreted a given measure in conceptually different ways (Sarstedt, Henseler \& Ringle, 2011). Prior research on PLS path modeling has largely neglected the issue of testing for measurement invariance in PLS multigroup analysis (Sarstedt, Henseler \& Ringle, 2011). Only recently Haenlein and Kaplan (2011) proposed a method to control for gamma change (which is a type of invariance). On the other hand, Rigdon, Ringle and Sarstedt (2010) argued that the insistence of measurement invariance across groups carries its own assumption that the impact of group membership is limited to the structural parameters of the inner model which is questionable or even implausible. Therefore, primarily due to the absence of a generally acceptable method to assess measurement invariance in PLS multigroup analysis and, secondly, the differences in opinions on the need for measurement invariance in PLS, the loadings in the outer model were not tested for invariance.

\section{Data analysis, results and discussion}

\section{Descriptive statistics}

The data is analyzed with SPSS 17.0 (SPSS, Inc.) to derive descriptive statistics. A total of 198 males and 267 females participated in the study. As can be seen from Table 1, the respondents are well dispersed across the various age categories. Almost half of the respondents (272 out of 465) earned R5 000 per month and less. All the respondents were non-users of cellphone banking and did send SMSs.

\section{Assessment of the measurement model}

Before testing for group differences in the structural models, the psychometric properties of the study variables were evaluated by means of a confirmatory factor analysis. The measurement model (outer model) for the Male and Female groups was separately assessed by using PLS to examine internal consistency reliability (ICR) and convergent and discriminant validity.

Internal consistency was assessed at the hand of two measures: Cronbach's alpha and composite reliability. As shown in Table 2, in both groups the alpha and the composite reliability for each latent variable are well above the suggested value of 0,7 . These results provide adequate support for the reliability of the measures.

Convergent validity was assessed by considering the item loadings, cross-loadings, average variance extracted, whilst discriminant validity was assessed by comparing the squared correlations between the constructs with the average variance extracted (AVE) for the constructs. In Table 2 all the loadings are above 0,7 and significant. Furthermore, for each construct in both models the AVE is above 0,5. An inspection of the cross-loadings in both groups also showed that no item had a higher loading on any other construct than on the intended construct. Therefore, the results provide sufficient evidence of convergent validity.

Discriminant validity was examined by comparing the variance-extracted percentages for any construct with the squared interconstruct correlations associated with that construct. For discriminant validity the variance-extracted estimate should be greater than the squared correlation estimate. As can be seen in Table 3 and Table 4, the squared interconstruct correlations are all lower than the AVE for both constructs associated with the correlation. These results provide good support for the discriminant validity of the measures.

Collectively, these results provide support for the overall quality of the measures in both groups. In particular, these statistics suggest that the component measures are reliable, are internally consistent, and have discriminant validity.

\section{Multi-group analysis}

With adequate measurement models, the next phase of the analysis involved estimating the structural model for each group and then to compare the path coefficients to test the hypotheses. The proposed model explains almost 50\% of attitude formation for men and approximately $46 \%$ of attitude formation for females (see Table 6). The determinants of Perceived usefulness explain more than $50 \%$ of the Perceived usefulness in both the models. However, the determinants of Perceived ease of use explain approximately $16 \%$ more of the variance in Perceived ease of use for females than for males $(0,4$ vs. 0,238$)$. The single determinant of Perceived self-efficacy in the model explains approximately $19 \%$ of the Perceived self-efficacy for men and approximately $13 \%$ of self-efficacy for females. 
Table 1: Demographics of respondents

\begin{tabular}{|c|c|c|c|c|c|}
\hline & & \multicolumn{4}{|c|}{ Gender } \\
\hline & & \multicolumn{2}{|c|}{ Male } & \multicolumn{2}{|c|}{ Female } \\
\hline & & Count & Row N \% & Count & Row N \% \\
\hline \multirow[t]{4}{*}{ Age group in years } & $18-30$ & 88 & $41,7 \%$ & 123 & $58,3 \%$ \\
\hline & $31-40$ & 69 & $47,6 \%$ & 76 & $52,4 \%$ \\
\hline & $41-50$ & 32 & $40,0 \%$ & 48 & $60,0 \%$ \\
\hline & 51 and older & 9 & $31,0 \%$ & 20 & $69,0 \%$ \\
\hline \multirow{2}{*}{ Employment status } & Fulltime employed & 151 & $44,4 \%$ & 189 & $55,6 \%$ \\
\hline & Part-time employed & 47 & $37,6 \%$ & 78 & $62,4 \%$ \\
\hline \multirow[t]{7}{*}{ Income per month } & R5 000 and less & 105 & $39,0 \%$ & 164 & $61,0 \%$ \\
\hline & R5 001 - R6 000 & 35 & $48,6 \%$ & 37 & $51,4 \%$ \\
\hline & R6 $001-$ R7 000 & 9 & $64,3 \%$ & 5 & $35,7 \%$ \\
\hline & R7 001 - R8 000 & 13 & $48,1 \%$ & 14 & $51,9 \%$ \\
\hline & R8 001 - R9 000 & 15 & $40,5 \%$ & 22 & $59,5 \%$ \\
\hline & R9 $001-$ R10 000 & 6 & $35,3 \%$ & 11 & $64,7 \%$ \\
\hline & R10 $001-$ R11 000 & 15 & $51,7 \%$ & 14 & $48,3 \%$ \\
\hline
\end{tabular}

Table 2: Construct reliability and convergent validity

\begin{tabular}{|c|c|c|c|c|c|c|c|c|c|}
\hline \multirow[t]{2}{*}{ Constructs } & \multirow[b]{2}{*}{ Items } & \multicolumn{4}{|c|}{ Males } & \multicolumn{4}{|c|}{ Females } \\
\hline & & Loading $\beta$ & A.V.E. & $\alpha^{*}$ & C.R.** & Loading $\beta$ & A.V.E. & $\alpha$ & C.R. \\
\hline \multirow[t]{4}{*}{ Attitude } & ATT1 & 0,805 & 0,773 & 0,901 & 0,932 & 0,871 & 0,807 & 0,92 & 0,943 \\
\hline & ATT2 & 0,914 & & & & 0,916 & & & \\
\hline & ATT3 & 0,885 & & & & 0,897 & & & \\
\hline & ATT4 & 0,910 & & & & 0,908 & & & \\
\hline \multirow[t]{4}{*}{ Cost } & $\mathrm{C} 1$ & 0,846 & 0,752 & 0,890 & 0,924 & 0,873 & 0,728 & 0,877 & 0,915 \\
\hline & $\mathrm{C} 2$ & 0,890 & & & & 0,823 & & & \\
\hline & $\mathrm{C} 3$ & 0,896 & & & & 0,866 & & & \\
\hline & $\mathrm{C} 4$ & 0,837 & & & & 0,851 & & & \\
\hline \multirow{4}{*}{$\begin{array}{l}\text { Facilitating } \\
\text { conditions }\end{array}$} & $\mathrm{FCl}$ & 0,823 & 0,671 & 0,840 & 0,891 & 0,855 & 0,727 & 0,874 & 0,914 \\
\hline & $\mathrm{FC} 2$ & 0,780 & & & & 0,859 & & & \\
\hline & $\mathrm{FC} 3$ & 0,835 & & & & 0,877 & & & \\
\hline & FC4 & 0,838 & & & & 0,818 & & & \\
\hline \multirow[t]{4}{*}{ Ease of use } & PEOU1 & 0,839 & 0,723 & 0,872 & 0,912 & 0,844 & 0,743 & 0,884 & 0,920 \\
\hline & PEOU2 & 0,846 & & & & 0,865 & & & \\
\hline & PEOU3 & 0,867 & & & & 0,854 & & & \\
\hline & PEOU4 & 0,848 & & & & 0,885 & & & \\
\hline \multirow[t]{4}{*}{ Usefulness } & PU1 & 0,735 & 0,671 & 0,835 & 0,890 & 0,839 & 0,699 & 0,856 & 0,903 \\
\hline & PU2 & 0,862 & & & & 0,840 & & & \\
\hline & PU3 & 0,824 & & & & 0,866 & & & \\
\hline & PU4 & 0,849 & & & & 0,798 & & & \\
\hline \multirow[t]{3}{*}{ Risk } & $\mathrm{R} 1$ & 0,885 & 0,781 & 0,860 & 0,915 & 0,798 & 0,715 & 0,810 & 0,882 \\
\hline & $\mathrm{R} 2$ & 0,903 & & & & 0,840 & & & \\
\hline & $\mathrm{R} 3$ & 0,862 & & & & 0,895 & & & \\
\hline \multirow[t]{3}{*}{ Self-efficacy } & SE1 & 0,836 & 0,715 & 0,800 & 0,882 & 0,853 & 0,718 & 0,804 & 0,884 \\
\hline & SE2 & 0,860 & & & & 0,811 & & & \\
\hline & SE3 & 0,841 & & & & 0,877 & & & \\
\hline
\end{tabular}


Table 3: Squared correlations between constructs in the male measurement model

\begin{tabular}{|c|c|c|c|c|c|c|c|}
\hline & Attitude & Cost & Ease of use & $\begin{array}{c}\text { Facilitating } \\
\text { conditions }\end{array}$ & Risk & Self-efficacy & Usefulness \\
\hline Attitude & 0,773 & & & & & & \\
\hline Cost & 0,100 & 0,752 & & & & & \\
\hline Ease of use & 0,337 & 0,026 & 0,723 & & & & \\
\hline $\begin{array}{c}\text { Facilitating } \\
\text { conditions }\end{array}$ & 0,185 & 0,001 & 0,160 & 0,671 & & & \\
\hline Risk & 0,134 & 0,248 & 0,043 & 0,014 & 0,781 & & \\
\hline Self-efficacy & 0,090 & 0,000 & 0,182 & 0,194 & 0,021 & 0,715 & \\
\hline Usefulness & 0,472 & 0,143 & 0,469 & 0,090 & 0,091 & 0,152 & 0,671 \\
\hline
\end{tabular}

Note: Figures in italics on the diagonal show the AVE; numbers below the diagonal represent squared construct correlations.

Table 4: Squared correlations between constructs in the female measurement model

\begin{tabular}{|c|c|c|c|c|c|c|c|}
\hline & Attitude & Cost & Ease of use & $\begin{array}{c}\text { Facilitating } \\
\text { conditions }\end{array}$ & Risk & Self-efficacy & Usefulness \\
\hline Attitude & 0,807 & & & & & & \\
\hline Cost & 0,073 & 0,728 & & & & & \\
\hline Ease of use & 0,405 & 0,078 & 0,743 & & & & \\
\hline $\begin{array}{l}\text { Facilitating } \\
\text { conditions }\end{array}$ & 0,177 & 0,019 & 0,165 & 0,727 & & & \\
\hline Risk & 0,107 & 0,230 & 0,099 & 0,024 & 0,715 & & \\
\hline Self-efficacy & 0,160 & 0,002 & 0,360 & 0,134 & 0,021 & 0,718 & \\
\hline Usefulness & 0,374 & 0,077 & 0,510 & 0,187 & 0,087 & 0,267 & 0,699 \\
\hline
\end{tabular}

Note: Figures in italics on the diagonal show the AVE; numbers below the diagonal represent squared construct correlations.

As hypothesized, the following relationships were stronger for males than for females: Perceived usefulness on Attitude, Perceived ease of use on Perceived usefulness and Perceived cost on Perceived Usefulness (see Table 5). Conversely, the following relationships were stronger for females as hypothesized: Perceived ease of use on Attitude, Perceived self-efficacy on Perceived ease of use and Facilitating conditions on Perceived Usefulness. It is important to point out that the influence of Facilitating conditions on Perceived ease of use and Facilitating conditions on Perceived self-efficacy for males and females were not as hypothesized. The results are rather that the influence of Facilitating conditions on Perceived ease of use and the influence of Facilitating conditions on Perceived self-efficacy are stronger for males than for females (see Table 5). Lastly, in both the male and female model the influence of Perceived risk on Perceived usefulness was not significant.

In the last column of Table 5, the t-values for the test used to test for significant differences between the path coefficients in the two models are presented. No path coefficient comparison was done for $\mathrm{H} 9$ as the path coefficient in both models was not significant. Of the eight remaining path coefficient comparisons, seven showed a significant difference between the path coefficients in the male and female model (see Table 5). The overall results of the study show that $\mathrm{H} 1, \mathrm{H} 2, \mathrm{H} 4, \mathrm{H} 7$ and $\mathrm{H} 8$ are supported, whilst $\mathrm{H} 3$, H5, H6 , and H9 are not supported (see Table 7).
To assess the goodness-of-fit (GoF) of the two PLS path models, the general criterion for evaluating GoF as proposed by Tenenhaus, Esposito Vinzi, Chatelin and Lauro (2005), was firstly followed. This criterion entails calculating the geometric mean of the average communality and the average $\mathrm{R}^{2}$. According to the results in Table 8 , the GoF index is satisfactory for both models. Additionally, the quality of both measurement models was assessed at the hand of the average cross-validated (CV) communality and the global quality of both structural models by means of the average CV-redundancy index. These indexes were calculated using the blindfolding method in SmartPLS. As shown in Table 8 , the values for both indexes are higher than the recommended standard of 0.3 (Tenenhaus et al., 2005).

\section{Discussion}

To the best of our knowledge, this study addresses a limitation in the existing body of knowledge on cellphone banking adoption behaviour. As mentioned previously, cellphone banking studies often did not consider the moderating effect of gender on adoption behaviour, overlooked the adoption behaviour of low-income non-users and mostly did not focus on a specific type of cellphone banking. The results of the study show that Perceived usefulness is a stronger predictor of Attitude for males than for females, as well as the influence of Perceived cost on Perceived usefulness. On the other hand, Perceived ease of use is a stronger predictor of Attitude towards WIGcellphone banking for females, as well as the influence of 
Perceived Self-efficacy on Perceived ease of use and Facilitating conditions on Perceived usefulness. Thus, to this point, the results are well supported by previous research on gender differences and the adoption of technology. Although the influence of Perceived ease of use on Perceived usefulness was stronger for males than for females, no significant difference between the two genders was found. Unexpectedly, the study results show the opposite influence as hypothesized for the influence of Facilitating conditions on Perceived ease of use and Perceived self-efficacy. These results do not suggest that Facilitating conditions are not important to females, but rather that Facilitating conditions influence Perceived ease of use and Perceived self-efficacy stronger for males than for females. A possible explanation could be that the females respondents, due to their general negative disposition towards technology, may not strongly believe that facilitating conditions would really assist them that much in making the use of the technology easier or improving their own self-efficacy. An alternative theory is that Facilitating conditions can have a stronger productivity association for males in a specific context than a process association for females. Through Facilitating conditions, men also learn the process; but for them, by learning the process they can use the technology more effectively and efficiently. No evidence was found that Perceived risk influenced Perceived Usefulness. This result may be due to the fact that the respondents were not using WIG-cellphone banking at the time of the survey and therefore the risks associated with the use of WIG-cellphone banking were not a significant factor for them. Their thought processes may have centered more on whether they would be able to use it (cost, facilitating conditions and self-efficacy) and the benefits of using WIG-cellphone banking. Indeed, Risk may become a significant factor once they start to use WIGcellphone banking. It may also be the case that the nonsignificant influence of Perceived risk on Perceived usefulness is due to a sampling idiosyncrasy.

Table 5: Comparison of the path coefficients in both samples

\begin{tabular}{|c|c|c|c|c|c|c|}
\hline \multicolumn{2}{|c|}{ Paths } & \multirow{2}{*}{$\begin{array}{r}\text { Path coeff. } \\
0,545^{* * *}\end{array}$} & \multirow{2}{*}{$\begin{array}{c}\text { Standard error } \\
0,101\end{array}$} & \multirow{2}{*}{$\begin{array}{c}\text { Path coeff. } \\
0,321^{*}\end{array}$} & \multirow{2}{*}{$\begin{array}{c}\text { Standard error } \\
0,144\end{array}$} & \multirow{2}{*}{$\begin{array}{c}\text { T-values comparing the two genders } \\
\text { Male - Female } \\
18,804^{* * *}\end{array}$} \\
\hline H1 & $\begin{array}{l}\text { Perceived usefulness -> } \\
\text { Attitude }\end{array}$ & & & & & \\
\hline $\mathrm{H} 2$ & $\begin{array}{l}\text { Perceived ease of use -> } \\
\text { Attitude }\end{array}$ & $0,207^{*}$ & 0,125 & $0,407 * *$ & 0,132 & $16,572 * * *$ \\
\hline $\mathrm{H} 3$ & $\begin{array}{l}\text { Perceived ease of use -> } \\
\text { Perceived usefulness }\end{array}$ & $0,619 * * *$ & 0,072 & 0,615 *** & 0,089 & 0,534 \\
\hline $\mathrm{H} 4$ & $\begin{array}{l}\text { Perceived self-efficacy -> } \\
\text { Perceived ease of use }\end{array}$ & $0,310 * *$ & 0,108 & $0,521 * * *$ & 0,091 & $22,892 * * *$ \\
\hline H5 & $\begin{array}{l}\text { Facilitating conditions -> } \\
\text { Perceived ease of use }\end{array}$ & $0,263 * *$ & 0,109 & $0,215^{*}$ & 0,108 & $4,681 * * *$ \\
\hline H6 & $\begin{array}{l}\text { Facilitating conditions -> } \\
\text { Perceived self-efficacy }\end{array}$ & $0,441 * * *$ & 0,089 & $0,366 * * *$ & 0,109 & $7,879 * * *$ \\
\hline $\mathrm{H} 7$ & $\begin{array}{l}\text { Facilitating conditions -> } \\
\text { Perceived usefulness }\end{array}$ & 0,040 & 0,104 & $0,167^{*}$ & 0,089 & $14,118 * * *$ \\
\hline H8 & $\begin{array}{l}\text { Perceived cost -> Perceived } \\
\text { usefulness }\end{array}$ & $-0,258 * * *$ & 0,074 & $-0,060$ & 0,086 & $26,003 * * *$ \\
\hline $\mathrm{H} 9$ & $\begin{array}{l}\text { Perceived risk -> Perceived } \\
\text { usefulness }\end{array}$ & $-0,040$ & 0,072 & $-0,046$ & 0,088 & Not tested \\
\hline
\end{tabular}

${ }^{*} \rho>, 05$

$* * \rho>, 01$

$* * * \rho>, 001$

Table 6: Variance explained in dependent variables

\begin{tabular}{lcc}
\hline Variable & Male model & Female model \\
& $\mathbf{R}^{\mathbf{2}}$ & 0,456 \\
\hline Attitude & 0,495 & 0,542 \\
Perceived usefulness & 0,545 & 0,4 \\
Perceived ease of use & 0,238 & 0,134 \\
Perceived self-efficacy & 0,194 & \\
\hline
\end{tabular}


Table 7: Summary of testing results

\begin{tabular}{|c|c|c|c|}
\hline & Relationship & Hypothesis & Result \\
\hline H1 & Perceived usefulness -> Attitude & $\mathrm{M}>\mathrm{F}$ & Supported \\
\hline $\mathrm{H} 2$ & Perceived ease of use $->$ Attitude & $\mathrm{M}<\mathrm{F}$ & Supported \\
\hline $\mathrm{H} 3$ & $\begin{array}{l}\text { Perceived ease of use } \rightarrow \text { Perceived } \\
\text { usefulness }\end{array}$ & $\mathrm{M} \neq \mathrm{F}$ & Not supported \\
\hline $\mathrm{H} 4$ & $\begin{array}{l}\text { Perceived self-efficacy -> Perceived ease } \\
\text { of use }\end{array}$ & $\mathrm{M}<\mathrm{F}$ & Supported \\
\hline H5 & $\begin{array}{l}\text { Facilitating conditions -> Perceived ease } \\
\text { of use }\end{array}$ & $\mathrm{M}<\mathrm{F}$ & Not supported \\
\hline H6 & $\begin{array}{l}\text { Facilitating conditions }->\text { Perceived self- } \\
\text { efficacy }\end{array}$ & $\mathrm{M}<\mathrm{F}$ & Not supported \\
\hline $\mathrm{H} 7$ & $\begin{array}{l}\text { Facilitating conditions } \quad \rightarrow \quad \text { Perceived } \\
\text { usefulness }\end{array}$ & $\mathrm{M}<\mathrm{F}$ & Supported \\
\hline $\mathrm{H} 8$ & Perceived cost $->$ Perceived usefulness & $\mathrm{M}>\mathrm{F}$ & Supported \\
\hline $\mathrm{H} 9$ & Perceived risk $->$ Perceived usefulness & $\mathrm{M}<\mathrm{F}$ & Not supported \\
\hline
\end{tabular}

Table 8: GoF and blindfolding results

\begin{tabular}{llll}
\hline & Male model & Female model & \\
\hline GoF & 0,517 & 0,530 \\
Mean CV-communality & 0,506 & 0,516 \\
Mean CV-redundancy & 0,365 & 0,369 & \\
\hline
\end{tabular}

\section{Implications for practice and research}

The practical contribution of this research is to show the potential important moderating effect of gender in the formation of attitude towards WIG-cellphone banking of low-income non-users. Confirmed gender differences in the study results show that to create more favourable attitudes among males, marketing communications must underpin the usefulness of the service in doing everyday banking. For example, banner displays in banks can be used to communicate the time-saving benefit and, most importantly, the facility to do banking 24 hours a day, seven days a week from almost any place. The cost of WIG-cellphone banking also has a significant influence on attitude formation for males, but not for females. Consequently, waiving certain WIG-cellphone banking transaction costs would make it more useful for low-income males. Alternatively, banks can also renounce certain charges if the customer makes use of other banking services. Knowledge of the availability of clear instructions, demonstrations and a help-desk will have a positive influence on low-income non-user males' perception that the service can be used effectively and efficiently to do banking transactions. It is therefore important that this must be communicated to potential users through existing marketing communication channels, as well as by bank employees during interactions with potential users. The first positive outcome of emphasizing the availability of user support for men is that it strengthens perceptions of Ease of use which directly influence usefulness perceptions. The second male-related positive outcome of emphasizing the availability of user support is that it strengthens the self-efficacy perceptions which also influence Perceived ease of use perceptions. Furthermore, the availability of facilitating conditions will also make WIG-cellphone banking more useful for females by strengthening their belief that they will have the necessary skills to use it. The results of the study also show that for females the Ease of use and Self-efficacy factors are more important than for men. Hence, marketing communications must foster the perception that WIG-cellphone banking is easy to use as that will create more a positive attitude among females. Banks can achieve this by marketing this type of cellphone banking just as SMS-cellphone banking instead of using 'WIG-cellphone banking' and 'SMS-cellphone banking' interchangeably. WIG (or Wireless Internet Gateway) has a very technical connotation and may therefore discourage female users to find out more about the service. Secondly, the system itself must be easy to use. Therefore, thorough usability research should be carried out in the design of the WIG-cellphone banking application. Marketing communications and user instructions must also be used to strengthen the if you know how to SMS, you will be able to do your banking by means of SMS-cellphone banking' perception.

The research has two limitations that impact on the generalization of the findings. The research reports findings of a study undertaken in a developing country. It may be incorrect to assume that these findings apply to consumers in developed countries. Furthermore, the target population was very specifically low-income earners. The findings may therefore not apply to other income groups. Future research can address these limitations. In this study, support for a moderating effect of gender on the Ease of use - Usefulness relationship could not be found. Given the conflicting findings presented in the theory development section of this study, more research is needed to gain an understanding of the conditions under which gender will moderate this relationship.

\section{Conclusion}

The research confirmed that gender is an important variable to consider in crafting WIG-cellphone banking marketing strategies. The adoption of WIG-cellphone banking can be 
enhanced by considering gender differences that affect Attitude towards WIG-cellphone banking.

\section{References}

Akinci, S., Aksoy, S. \& Atilgan, E. 2004. 'Adoption of Internet banking among sophisticated consumer segments in an advanced developing country', International Journal of Bank Marketing, 22(3): 212-232.

Alsajjan, B. \& Dennis, C. 2009. 'Internet banking acceptance model: Cross-market examination', Journal of Business Research, 63(9-10): 957-963.

Amin, H., Hamid, M.R.A., Tanakinjal, G.H. \& Lada, S. 2006. 'Undergraduate attitudes and expectations for mobile banking', Journal of Internet Banking and Commerce, 11(3). [online]

URL:http://www.arraydev.com/commerce/JIBC/2006-

12/JIBC2 htm.

Brown, I., Cajee, Z., Davies, D. \& Stroebel, S. 2003. 'Cell phone banking: Predictions of adoption in South Africa - an exploratory study', International Journal of Information Management, 23(5): 381-394.

Cheung, W., Chang, M.K. \& Lai, V.S. 2000. 'Prediction of Internet and world wide web usage at work: A test of an extended Triandis model', Decision Support Systems, 30(1): 83-100.

Chinn, W. 1998. 'The partial least squares approach to structural equation modeling'. In Marcoulides, G.A. (Ed.). Modern methods for business research. Mahwah, NJ: Lawrences Erlbaum Associates, pp. 295-358.

Compeau, D.R. \& Higgins, C.A. 1995. 'Computer selfefficacy: Development of a measure and initial test', MIS Quarterly, 19(2): 189-211.

Dabholkar, P. \& Bagozzi, R. 2002. 'An attitudinal model of technology-based self-service: Moderating effects of consumer traits and situational factors', Journal of the Academy of Marketing Science, 30(3): 184-201.

Davis, F.D. 1989. 'Perceived usefulness, perceived ease of use, and user acceptance of information technology', MIS Quarterly, 13(3): 319-340.

Featherman, M.S. \& Pavlou, P.A. 2003. 'Predicting eservices adoption: A perceived risk facets perspective', International Journal of Human-Computer Studies, 59(4): 451-474.

Garbarino, E. \& Strahilevitz, M. 2004. 'Gender differences in the perceived risk of buying online and the effects of receiving a site recommendation', Journal of Business Research, 57(7): 768-775.

Grabnet-Krăuter, S. \& Kaluscha, E.A. 2003. 'Empirical research in online-trust: A review and critical assessment', International Journal of Human Computer Studies, 58: 783812.
Gu, J.-C., Lee, S.-C. \& Suh, Y.-H. 2009. 'Determinants of behavioral intention to mobile banking', Expert Systems with Applications, 36(9): 11605-11616.

Haenlein, M. \& Kaplan, A.M. 2011. 'The influence of observed heterogeneity on path coefficients significance: Technology acceptance within the marketing discipline', Journal of Marketing Theory and Practice, 19(2): 153-168.

Henseler, J., Ringle, C.M. \& Sinkovics, R.R. 2009. 'The use of partial least squares path modeling in international marketing', Advances in International Marketing, 20(1): 277-319.

Hwang, Y. 2010. 'The moderating effects of gender on ecommerce systems adoption factors: An empirical investigation', Computers in Human Behavior, 26(6): 1753 1760.

Igbaria, M. \& Iivari, J. 1995. 'The effects of self-efficacy on computer usage', Omega, 23(6): 587-605.

Im, I., Kim, Y. \& Han, H.-J. 2008. 'The effects of perceived risk and technology type on users' acceptance of technologies', Information \& Management, 45(1): 1-9.

Kabanda, S.K., Brown, I., Nyamakura, V. \& Keshav, J. 2010. 'South African banks and their online privacy policy statements: A content analysis ', South African Journal of Information Management, 12(1). [online] URL:http://www.sajim.co.za/index.php/SAJIM/article/ view/418/410.

Keil, M., Tan, B.C.Y., Wei, K. \& Saarinen, T. 2000. 'A cross-cultural study on escalation of commitment behavior in software projects.' MIS Quarterly, 24(2): 299-325.

Kim, D.-Y., Lehto, X.Y. \& Morrison, A.M. 2007. 'Gender differences in online travel information search: Implications for marketing communications on the internet', Tourism Management, 28(2): 423-433.

Kuo, Y.-F. \& Yen, S.-N. 2009. 'Towards an understanding of the behavioral intention to use $3 \mathrm{G}$ mobile value-added services', Computers in Human Behavior, 25(1): 103-110.

Laforet, S. \& Li, X. 2005. 'Consumers' attitudes towards online and mobile banking in China', International Journal of Bank Marketing, 23(5): 362-380.

Lai, V.S. \& Li, H. 2005. 'Technology acceptance model for internet banking: An invariance analysis', Information \& Management, 42(2): 373-386.

Lee, M.-C. 2009. 'Factors influencing the adoption of internet banking: An integration of TAM and TPB with perceived risk and perceived benefit', Electronic Commerce Research and Applications, 8(3): 130-141.

Li, N. \& Kirkup, G. 2007. 'Gender and cultural differences in Internet use: A study of China and the UK', Computers \& Education, 48(2): 301-317. 
Luarn, P. \& Lin, H.-H. 2005. 'Toward an understanding of the behavioral intention to use mobile banking', Computers in Human Behavior, 21(6): 873-891.

Mathieson, K. 1991. 'Predicting user intentions: Comparing the Technology Acceptance Model with the theory of planned behavior', Information Systems Research, 2(3): 173191.

Naidu, E. 2006. 'Cellphone companies push the power of mobile business services to hook consumers', Sunday Independent, November 19. [online] URL: http://www.sundayindependent.

co.za/index.php?fArticleId=3546847.

Nysveen, H., Pedersen, P.E. \& Thorbjørnsen, H. 2005. 'Explaining intention to use mobile chat services: Moderating effects of gender', Journal of Consumer Marketing, 22(5): 247-256.

Ong, C.-S. \& Lai, J.-Y. 2006. 'Gender differences in perceptions and relationships among dominants of elearning acceptance', Computers in Human Behavior, 22(5): 816-829.

Pedersen, P.E. 2005. 'Adoption of mobile Internet services: An exploratory study of mobile commerce early adopters', Journal of Organizational Computing and Electronic Commerce, 15(3): 203-222.

Porter, C.E. \& Donthu, N. 2006. 'Using the technology acceptance model to explain how attitudes determine Internet usage: The role of perceived access barriers and demographics', Journal of Business Research, 59(9): 9991007.

Powell, M. \& Ansic, D. 1997. 'Gender differences in risk behaviour in financial decision-making: An experimental analysis', Journal of Economic Psychology, 18(6): 605-628.

Ridgon, E.E., Ringle, C.M. \& Sarstedt, M. 2010. 'Structural modelling of heterogeneous data with partial least squares'. In N.K. Malhotra (Ed.). Review in Marketing Research, 7: 255-296.

Ringle, C.M., Wende, S. \& Will, A. 2005. 'Smart-pls 2.0 (beta)'. [online] URL: www.smartpls.de.

Riquelme, H.E. \& Rios, R.E. 2010. 'The moderating effect of gender in the adoption of mobile banking', International Journal of Bank Marketing, 28(5): 328-341.

Roca, J.C., Chiu, C.-M. \& Martínez, F.J. 2006. 'Understanding e-learning continuance intention: An extension of the Technology Acceptance Model', International Journal of Human-Computer Studies, 64(8): 683-696.

Sarstedt, M., Henseler, J. \& Ringle, M. 2011. . 'Multigroup analysis in Partial Least Squares (PLS) path modelling: Alternative methods and empirical results', Advance in International Marketing, 22: 195-218.
Shen, S. 2010. 'Hype cycle for consumer services and mobile applications, 2010'. Gartner, Inc. [online] URL: http://my.gartner.com/portal/server.pt?open=512\&objID=26 $0 \&$ mode $=2 \&$ PageID

$=3460702 \&$ resId $=1409321 \&$ ref $=$ QuickSearch \& content $=$ htm l\#h-N70406.

Sun, H. \& Zhang, P. 2006. 'The role of moderating factors in user technology acceptance', International Journal of Human-Computer Studies, 64(2): 53-78.

Suoranta, M. \& Mattila, M. 2004. 'Mobile banking and consumer behaviour. New insights into the diffusion pattern', Journal of Financial Services Marketing, 8(4): 354366.

Tan, M. \& Teo, T.S.H. 2000. 'Factors influencing the adoption of Internet banking', Journal of the Association for Information Systems, 1(5): 1-42.

Taylor, S. \& Todd, P. 1995. 'Assessing it usage: The role of prior experience', MIS Quarterly, 19(4): 561-570.

Tenenhaus, M., Esposito Vinzi, V., Chatelin, Y.M. \& Lauro, C. 2005. 'Pls path modeling', Computational statistics \& data analysis, 48: 159-205.

Van Slyke, C., Comunale, C.L. \& Belanger, F. 2002. 'Gender differences in perceptions of web-based shopping', Communications of the ACM, 45(8): 82-86.

Venkatesh, V. 2000. 'Determinants of perceived ease of use: Integrating control, intrinsic motivation, and emotion into the technology acceptance model', Information Systems Research, 11(4): 342-365.

Venkatesh, V., Brown, S.A., Maruping, L.M. \& Bala, H. 2008. 'Predicting different conceptualizations of system use: The competing roles of behavioral intention, facilitating conditions, and behavioral expectation', MIS Quarterly, 32(3): 483-502.

Venkatesh, V. \& Morris, M.G. 2000. 'Why don't men ever stop to ask for directions? Gender, social influence, and their role in technology acceptance and usage behavior', MIS Quarterly, 24(1): 115-139.

Wang, Y.-S., Lin, H.-H. \& Luarn, P. 2006. 'Predicting consumer intention to use mobile banking service', Information Systems Journal, 16(2): 157-179.

Wang, Y.-S. \& Wang, H.-Y. 2008. 'Developing and validating an instrument for measuring mobile computing self-efficacy', CyberPsychology \& Behavior, 11(4): 405413.

Whitfield, B. 2006. 'Banks burn cash on cell banking'. [online] URL:http://www fin24.co.za/articles/default/display _article.aspx? Nav=ns\&ArticleID=1518-1786_2022212.

Wu, I.-L. \& Chen, J.-L. 2005. 'An extension of trust and TAM model with TPB in the initial adoption of on-line tax: 
An empirical study', International Journal of HumanComputer Studies, 62(6): 784-808.

Wu, J.-H. \& Wang, S.-C. 2005. 'What drives mobile commerce? An empirical evaluation of the revised technology acceptance model', Information \& Management, 42(5): 719-729. 


\section{ANNEXURE A}

\section{Facilitating conditions:}

The authors would use or consider SMS-cellphone banking if:

\begin{tabular}{l|l}
\hline FC1 & There is a substantial support from the banks (manuals, demonstrations). \\
\hline FC2 & Clear instructions are provided to use SMS-cellphone banking effectively. \\
\hline FC3 & SMS-cellphone banking is readily accessible. \\
\hline FC4 & Helpdesk is available to assist with any SMS-cellphone banking difficulties. \\
\hline
\end{tabular}

Risk:

\begin{tabular}{l|l}
\hline R1 & I think using SMS-cellphone banking puts personal details at risk for confidentiality. \\
\hline R2 & I think using SMS-cellphone banking in paying bills has a potential risk. \\
\hline R3 & I think SMS-cellphone banking is more risky than other banking options. \\
\hline
\end{tabular}

\begin{tabular}{|c|}
\hline Cost: \\
\hline $\mathrm{C} 1$ \\
\hline $\mathrm{C} 2$ \\
\hline C3 \\
\hline $\mathrm{C} 4$ \\
\hline
\end{tabular}

I think bank charges are expensive when using SMS-cellphone banking. I think SMS charge is expensive when using SMS-cellphone banking. I think SMS alerts from the bank are expensive when using SMS-cellphone banking.

Self-efficacy:

\begin{tabular}{l|l}
\hline SE1 & I would easily understand how SMS-cellphone banking works. \\
\hline SE2 & I would be able to use SMS-cellphone banking even if there could be no one around to show me how to use it. \\
\hline SE3 & I would feel comfortable using SMS-cellphone banking on my own. \\
\hline SE4 & I could complete SMS-cellphone banking if I had enough time. \\
\hline
\end{tabular}

Perceived ease of use:

\begin{tabular}{l|l}
\hline PEOU1 & SMS-cellphone banking will be easy to understand. \\
\hline PEOU2 & Getting the information I want from SMS-cellphone banking will be easy. \\
\hline PEOU3 & Becoming skilful at using SMS-cellphone banking is easy. (Knowing shortcut keys or Advanced options). \\
\hline PEOU4 & SMS-cellphone banking will be easy to use. \\
\hline
\end{tabular}

\section{Perceived usefulness:}

\begin{tabular}{l|l}
\hline PU1 & Using SMS-cellphone banking will save me time. \\
\hline PU2 & Using SMS-cellphone banking will save me money. \\
\hline PU3 & Using SMS-cellphone banking is convenient. \\
\hline PU4 & Using SMS-cellphone banking is useful for banking. \\
\hline
\end{tabular}

\begin{tabular}{l|l}
\multicolumn{2}{l}{ Attitude: } \\
\hline ATT1 & In my opinion it is desirable to use SMS-cellphone banking. \\
\hline ATT2 & I think it will be good for me to use SMS-cellphone banking. \\
\hline ATT3 & Overall, my attitude towards SMS-cellphone banking is favourable. \\
\hline ATT4 & I think using SMS-cellphone banking is a good idea. \\
\hline
\end{tabular}

